\title{
Evaluasi Program Bimbingan dan Konseling dalam Mengatasi Perilaku Membolos Peserta Didik di Sekolah Menengah Atas (SMA) YP Unila Bandar Lampung
}

\author{
Defriyanto, Dewi Jami Rahayu
}

\author{
Dosen dan Mahasiswa Fakultas Tarbiyah dan Keguruan, IAIN Raden Intan Lampung \\ Diterima: Oktober 2015. Disetujui: November 2015. Dipublikasikan: Desember 2015
}

\begin{abstract}
Abstrak: Layanan bimbingan dan konseling di sekolah merupakan pelayanan bantuan untuk peserta didik baik perorangan ataupun kelompok agar dapat menyelesaikan permasalahan yang dihadapi. Pada pelaksanaan kegiatan layanan tersebut mengacu pada program yang telah direncanakan ole guru pembimbing dengan memperhatikan kebutuhan dan permasalahan peserta didik. Di akhiri pelaksanaan kegiatan layanan, salah satu tahapan yang harus dilaksanakan oleh guru pembimbing adalah evaluasi. Permasalahan dalam penelitian ini adalah bagaimana pelaksanaan program layanan bimbingan dan konseling dalam mengatasi perilaku membolos peserta didik di Sekolah Menengah Atas (SMA) YP Unila Bandar lampung. Jenis penelitian kualitatif ini yaitu penelitian lapangan (field research) dengan jenis penelitian deskriptif. Populasi dalam penelitian ini yaitu seluruh peserta didik kelas $\mathrm{X}$, kepala sekolah, waka kesiswaan, dan guru pembimbing. Teknik pengumpulan data menggunakan metode interview, observasi dan dokumentasi. Hasil penelitian ini menunjukkan pelaksanaan kegiatan evaluasi program layanan bimbingan dan konseling dalam mengatasi perilaku membolos peserta didik kelas X di Sekolah Menengah Atas (SMA) YP Unila Bandar Lampung.

Kata Kunci: Evaluasi Program Bimbingan dan Konseling; Perilaku Membolos
\end{abstract}

\section{Pendahuluan}

Pendukung utama tercapainya sasaran pembangunan manusia Indonesia bermutu adalah pendidikan yang bermutu. Proses penyelenggaraan pendidikan yang bermutu tidak cukup hanya dilakukan melalui transformasi ilmu pengetahuan dan teknologi. Pada era perkembangan ilmu pengetahuan dan teknologi dewasa ini belajar tidak dapat ditunda-tunda lagi. Jika individu malas belajar maka akan tertinggal dan mengalami kesulitan dalam mengikuti laju perkembangan ilmu pengetahuan dan teknologi, bahkan akan mengalami kesulitan dalam menerima dan menguasai materi pelajaran yang diberikan oleh guru di sekolah.

Pendidikan merupakan unsur yang tidak dapat dipisahkan dari diri manusia, mulai dari kandungan sampai beranjak dewasa kemudian tua. Manusia mengalami proses pendidikan yang didapatkan dari orang tua, masyarakat dan lingkungannya. Pendidikan bagaikan cahaya penerang yang berusaha menuntun manusia dalam menentukan arah, tujuan dan makna kehidupan. Manusia sangat membutuhkan pendidikan melalui proses penyadaran yang berusaha menggali dan mengebangkan potensi dirinya melalui proses belajar.

Pendidikan merupakan sarana untuk menuju kepada pertumbuhan dan perkembangan bangsa, hal ini di angkat dalam Undang-Undang No 20 tahun 2003 tentang Sistem Pendidikan Nasional (SISDIKNAS), yaitu: pendidikan nasional berfungsi mengembangkan kemampuan dan membentuk watak serta peradaban bangsa yang bermartabat dalam rangka mencerdaskan kehidupan bangsa, bertujuan untuk berkembangnya potensi peserta didik agar menjadi manusia yang beriman dan bertakwa kepada Tuhan Yang Maha Esa, berakhlak mulia, sehat, berilmu, kreatif, mandiri, dan menjadi warga negara yang demokratis serta bertanggung jawab (Nasional, 2003).

Tujuan pendidikan nasional di atas dapat dicapai apabila didukung oleh komponen pendidikan diantaranya orang tua sebagai pendidik utama dan pertama dirumah tangga, guru sebagai pendidik di sekolah. Pendidik pada hakekatnya berlangsung dalam suatu proses. Proses itu berupa transformasi nilai-nilai pengetahuan, teknologi dan keterampilan. Penerima proses adalah peserta didik yang sedang tumbuh dan berkembang menuju ke arah pendewasaan 
kepribadian dan penguasaan pengetahuan, sebab hanya melalui proses pendidikan yang baik maka manusia akan mampu meraih dan menguasai ilmu pengetahuan untuk bekal hidupnya. Melalui proses pendidikan seorang dapat mengetahui apa yang tidak diketahuinya.

Kebutuhan akan hubungan bantuan (helping relationship), terutama layanan bimbingan dn konseling, pada dasarnya timbul dari diri dan luar individu yang melahirkan seperangkat pertanyaan mengenai apakah yang harus diperbuat individu. Dalam konsep Islam, pengembangan diri merupakan sikap dan perilaku yang sangat diistimewakan. Manusia yang mampu mengoptimalkan potensi dirinnya, sehingga menjadi pakar dalam disiplin ilmu pengetahuan dijadikan kedudukan yang mulia disisi Allah SWT.

Di era modern dewasa ini, layanan bimbingan dan konseling dalam institusi pendidikan mengalami perkembangan dan perluasan untuk mencapai kompetensi dalam layanan bimbingan dan konseling di sekolah secara dinamis mulai mengenal dengan keberadaan layanan bimbingan dan konseling di institusi pendidikan sebagai salah satu alat yang penting dalam mewujudkan tercapainya tujuan pendidikan yang diinginkan, dan memberikan layanan bantuan kepada setiap peserta didik yang memiliki permasalahan.

Bimbingan adalah bantuan yang diberikan kepada individu dalam membuat pilihanpilihan dan penyesuaian yang bijaksana. Bantuan itu berdasarkan atas prinsip demokrasi yang merupakan tugas dan hak setiap individu untuk memilih jalan hidupnya sendiri sejauh tidak mencampuri hak orang lain. Kemampuan membuat pilihan seperti itu tidak diturunkan (diwariskan), tetapi harus dikembangkan (Prayitno \& Ermananti, 2004). Sedangkan konseling adalah semua bentuk hubungan antara dua orang, dimana yang seorang, yaitu klien dibantu untuk lebih mampu menyesuaikan diri secara efektif terhadap dirinya sendiri dan lingkungannya. Suasana hubungan konseling ini meliputi pengguna wawancara untuk memperoleh dan memberikan berbagai informasi, melatih atau mengajar, meningkatkan kematangan, memberikan bantuan melalui pengambilan keputusan dan usaha-usaha penyembuhan (terapi) (Nurikhsan, 2005).

Bimbingan dan Konseling pada hakikatnya bukanlah merupakan suatu hal yang baru. Sejak dari dahulu bimbingan dan konseling ini sudah ada zaman menghadapi kesulitan, orang biasanya meminta bantuan orang lain untuk turut serta memecahkan kesulitan tersebut. Di dalam memecahkan masalah-masalah tersebut terlihat adanya perbedaan antara orang-orang tua kita pada masa dahulu dengan orang-orang tua kita pada masa sekarang. Perbedaan ini terletak pada pendektan (approach) yang ditempuh dalam mengahadapi masalah (Aqib, 2012).

Pelaksanaan bimbingan dan konseling di sekolah secara umum bertujuan untuk membantu individu untuk mengembangkan diri secara optimal, sesuai dengan tahap perkembangan dan prediposisi yang dimilikinya (seperti kemampuan dasar dan bakatbakatnya) berbagai latar belakang keluarga, pendidikan, status ekonomi serta situasi dengan tuntutan positif lingkunganya. Sedangkan tujuan khusus merupakan penjabaran tujuan umum tersebut yang dikaitkan secara langsung dengan permasalahan yang dialami oleh individu yang bersangkutan sesuai kompleksitas permasalahan itu (Prayitno, 2001).

Adapun fungsi bimbingan dan konseling di sekolah-sekolah itu tidak hanya bersifat memberi bantuan kepada peserta didik untuk berusaha mengatasi kesulitan yang dihadapi. Pengarahan yang diberikan kepada peserta didik yaitu dengan memberikan secara langsung jawaban-jawaban terhadap permasalahan yang menjadi penyebab kesulitan yang dihadapi/dialami peserta didik. Guru juga memberikan saran-saran dan nasihat kepada peserta didik bagaimana peserta didik harus berbuat dan menghadapi permasalahan yang dihadapinya (Arifin, 2005).

Berkenaan dengan kenakalan remaja, adapun beberapa jenis/bentuk kenakalan remaja yang ada di sekolah misalnya peserta didik yang tidak mengikuti pelajaran, membolos, merokok di lingkungan sekolah, tawuran antar pelajar, peserta didik yang suka membuka gambar atau situs porno, siswa yang menggunakan pakaian yang tidak sesuai aturan dan lain 
sebagainya. Jensen sebagaimana yang telah dikutip oleh Sarlito Wirawan Sarwono membagi kenakalan anak menjadi empat jenis, namun kenakalan yang sering ada di sekolah yaitu kenakalan yang melawan status, seperti merokok, pelajar sering membolos sebagai anak melawan orang tua, membantah perintah orang tua dan lainya (Sarwono, 2011).

Kaitanya dengan kenakalan remaja di sekolah, kenakalan remaja yang sangat marak diperbincangkan adalah masalah membolos. Prilaku membolos sebenarnya bukanlah hal yang baru lagi bagi kalangan pelajar, setidaknya mereka yang pernah duduk di dunia pendidikan, sebab perilakumembolos itu sendiri telah ada sejak dulu. Menurut Bachri Thalib, akibat dari pelaku penyimpang khususnya membolos tersebut dapat berdampak bagi diri sendiri dan orang lain, diantaranya ketidakmampuan berprestasi, peserta didik menggunakan waktu luangnya untuk mengganggu temannya di kelas, kegelisahan yang tidak realistis, kesedihan dan depresi, kesulitan bergaul dan ketergantungan yang berlebihan kepada guru (Thalib, 2010).

Menurut Kun Maryati dan Juju Suryawati menjelaskan bahwa perilaku membolos merupakan salah satu bentuk penyimpangan perilaku, penyimpangan itu terjadi karena adanya proses labeling (pemberian julukan, cap, atau merk yang dianggap tidak sesuai dengan norma dan nilai sosial) yang diterima seseorang yang membuatnya melakukan penyimpangan (Maryati \& Suryawati, 2010). Menurut Surya, membolos adalah bentuk perilaku menginggalkan aktivitas yang seharusnya dilakukan dalam waktu tertentu dan tugas atau peranan tertentu tanpa pemberitahuan yang jelas (Surya, 2005).

Perilaku membolos ini disebabkan oleh beberapa faktor, yaitu: 1) Faktor pribadi, setiap anak mempunyai kepribadian khusus. Kepribadian ini bisa menjadi sumber munculnya perilaku menyimpang. 2) Faktor keluarga, merupakan faktor unit sosial paling kecil dalam masyarakat yang peranannya besar sekali terhadap perkembangan sosial, terlebih awal-awal perkembangan yang menjadi landasan perkembangan kepribadian selanjutnya (Gunarsa, 2004). menurut M. Surya, kebiasaan membolos dapat bersumber dari berbagai faktor, baik internal maupun eksternal, yaitu sebagai berikut: 1) Secara internal, kebiasaan membolos bersumber dari kondisi di dalam diri peseta didik yang antara lain berkaitan erat dengan faktor kecakapan potensial maupun actual, kematangan perkembangan, sikap dan kebiasaan, minat, kestabilan emosional, pengamalan, kemandirian, kualitas kepribadian, dan sebagainya. 2) Faktor eksternal yang mempengaruhi lingkungan keluarga, sekolah, masyarakat dan pergaulan sebaya. Faktor keluarga yang menjadi sumber timbulnya kebiasaan membolos, yaitu suasana keluarga yang kurang mendukung, keterbatasan sarana dalam keluarga, kurangnya keharmonisan hubungan dalam keluarga. Lingkungan sekolah yang kurang baik dapat menjadi sumber timbulnya kebiasaan membolos seperti suasana kelas kurang menyenangkan, sikap guru yang kurang baik, hubungan antar siswa yang kurng baik, lingkungan sekolah yang kurang baik, materi pelajaran yang kurang menarik.

Adapun indikator atau ciri-ciri prilaku membolos yang ada dalam diri peserta didik yaitu: adanya aspek lahiriah dan aspek simbolik yang tersembunyi. Aspek lahiriah dibagi menjadi dua, yakni deviasi yang verbal dalam bentuk kata-kata makian, kata-kata kotor dan lainnya; dan deviasi lahiriah non-verbal yang nyata kelihatan. Sedangkan aspek simbolik yang tersembunyi mencakup sikap-sikap hidup, emosi-emosi, sentiment-sentimen dan motivasimotivasi yang mengembangkan tingkahlaku menyimpang khususnya membolos (Kartono, 2011).

Menurut Mustaqim dan Abdul Wahib indikator atau ciri-ciri prilaku membolos yang ada dalam diri peserta didik yaitu: 1) Suka mengantuk. 2) Suka menyindir. 3) Terlambat sekolah. 4) Kelainan fisik. 5) Pergaulan buruk. 6) Pembohong. 7) Pemalas dan, 8) Pengalaman hidup (Mustaqim \& Wahib, 2003). Untuk menangani dan mecegah terjadinya perilaku membolos peserta didik, maka diperlukan sebuah terobosan baru yakni dengan menasehati dan memberikan layanan konseling. Itulah sebabnya layanan bimbingan dan konseling sangat di perlukan dalam sebuah lembaga pendidikan. Di sekola guru bimbingan dan konseling (BK) 
bertugas membantu memecahkan masalah yang dihadapi peserta didik, termasuk di dalamnya perilaku membolos. Guru BK menjadi teman untuk membahas masalah pribadinya. Agarpeserta didik mampung mengatasi masalahnya sendiri dan dapat berfikir secara positif, tanpa harus meragukan kerahasiannya, karena guru BK mempunyai kode etik yang di dalamnya terdapat asas- asas konseling.

Salah satu upaya yang dapat dlakukan oleh guru BK yaitu melalui pendekatan tingah laku (behavior). Pendekatan behavior menekankan pada dimensi kognitif individu dan menawarkan berbagai metode yang berorentasi pada tindakan (action-oriented) untuk membantu mengambil langkah yang jelas dalam mengubah tingkah laku. Setiap tangka laku dapat di pelajari, tingkah laku lama dapat diganti dengan tingkah laku baru, dan manusia memiliki potensi untuk berperilaku baik atau buruk, tepat atau salah (Wahyuni Komalasari, 2011).

Sedangkan menurut Gunarsa, pendekatan behaviour menganggap perilaku seseorang dengan semua aspeknya sekrang ini adalah hasil dari proses belajar dan hal ini diperoleh dalam interaksinya dengan dunia luar. Pendekatan behaviour merupakan perlaku manusia dair berbagai aspek yang dipengaruhi dari proses belajar yang diperoleh dari lingkungan sekitarnya (Gunarsa S., 2012).

\section{Metode Penelitian}

Jenis penelitian ini adalah penelitian lapangan (field research), yaitu "penelitian lapangan yang dilakukan dalam kancah kehidupan yang sebenarnya", Dengan pendekatan kualitatif, yaitu sebuah penelitian pada data yang berbentuk data, kalimat, skema dan gambar. Desain penelitian ini bersifat deskriptif, yaitu "suatu metode dalam meneliti suatu objek yang bertujuan membuat deskripsi, gambaran atau lukisan secara sistematis dan objektif, mengenai fakta-fakta, sifat-sifat, ciri-ciri serta hubungan diantara unsur-unsur yang ada atau fenomena tertentu" (M.S, 2005). Populasi dalam penelitian ini yaitu seluruh peserta didik kelas X, kepala sekolah, waka kesiswaan, dan guru pembimbing. Pengambilan sampel dalam penelitian dilakukan dengan menggunakan teknik purposive sampling, yakni peserta didik yang membolos $\geq 3 \mathrm{x}$ dalam satu semester. Metode pengumpulan data menggunakan metode interview adalah teknik pengumpulan data yang digunakan peneliti untuk mendapatkan keterangan- keterangan lisan melalui bercakap-cakap dan berhadapan muka dengan orang yang dapat memberikan keterangan kepada si peneliti (Mardalis, 2004)., Observasi yang digunakan dalam penelit ini adalah observasi non- partisipan karena peneliti tidak mengambil bagian secara penuh dari aktifitas objek yang diteliti, dan dokumentasi adalah "mencari data mengenai hal-hal atau sesuatu yang berkaitan dengan masalah variable yang berupa catatan, tranksip, buku, surat kabar, majalah, prasasti, notulen rapat, buku langger". Dalam mengola dan menganalisis data yang telah diperoleh dari lapangan tersebut, penulis menggunakan Analisa kualitatif (non-statistik) karena data yang diperoleh merupakan data deskriptif, sebagaimana Sumadi Suryabrata mengatakan bahwa: "Penelitian harus memastikan pola analisis mana yang akan digunakannya, apakah analisis statistik ataukah analisis non- statistik. Pemilihan ini tergantung pada data yang terkumpul statistic sesuai dengan data kuantitatif atau data yang dikualifikasikan yaitu dalam bentuk bilangan, sedangkan analisis non-statistik sesuai dengan data deskriptif" (Suryabrata, 2001).

\section{Hasil dan Pembahasan}

Menurut hasil wawancara, para narasumber menjelaskan ada beberapa layanan yang diadakan di sekolah ini, diantaranya layanan bimbingan pribadi, bimbingan sosial, bimbingan belajar, bimbingan karir, layanan orientasi, layanan informasi, layanan penguasaan konten, konseling individual, dan konseling kelompok. Namun dalam pemecahan masalah perilaku 
membolos, pihak sekolah menerapkan layanan konseling individual dan kelompok (Dokumentasi SMA YP Unila Bandar Lampung, 2015).

Menurut ibu Devina, "Layanan konseling yang diterapkan di sekolah ini ada beberapa macam, diantaranya yaitu konseling individual, konseling layanan konten, konseling kelompok, dan lainya. Penerapan layanan konseling ini adalah pada dasarnya adalah untuk pemecahan masalah peserta didik, pembentukan kepribadian peserta didik, dan mengambangakan kedisiplinan belajar peserta didik, dari beberapa layanan konseling yang ada, konseling individual dan kelompok merupakan layanan yang selalu diterapkan di sekolah untuk mengatasi perilaku menyimpang seperti membolos (Devina, 2015). Untuk penunjang kegiatan layanan bimbingan dan konseling, ibu Devina mengungkapkan bahwa konselor SMA YP Unila Bandar Lampung melaksanakan kegiatan pendukung layanan bimbingan dan konseling, pendapat ini di perkuat oleh pernyataan bapak Asadudin yang menyatakan hal yang sama dengan ibu Devina.

Sehingga dapat disimpulkan bahwa dalam proses pemberian layanan bimbingan dan konsling di SMA YP Unila Bandar Lampung tidak berbeda dengan pelayanan bimbingan dan konseling pada umumnya yaitu layanan yang diberikan sesuai dengan pola layanan BK 17 plus. Perbedaan yang terlihat hanya terjadi pada waktu pemberian layanan dan format pemberian layanan, dimana pemberian layanan dilakukan pada saat jam kosong atau jam tertentu sesuai dengan jadwal, dan format yang digunakan kelompok dan individual.

Konsep "BK Pola 17 Plus" walaupun konsepnya singkat namun cukup membawa peserta didik pada pemahaman awal tentang bimbingan dan konseling. Pola ini benar- benar memperjelas apa yang harus dilakukan guru pembimbing dalam penyelenggaraan $\mathrm{BK}$ di sekolah. Dapat dipastikan bahwa "BK Pola 17 Plus" menjadi acuan guru pembimbing dalam melaksanakan BK di sekolah (Suhertina, 2008). BK Pola 17 Plus yang dilaksanakan oleh SMA YP Unila Bandar Lampung ini berpedoman pada teori di buku Suhertina, dan sesuai dengan jurnal pelaksanaan BK Pola 17 Plus oleh Riri Yunika dkk (Yunika, Alizamar, \& Sukmawati, 2013).

Berdasarkan hasil observasi peneliti, layanan yang lebih sering dilakukan konselor adalah layanan individual dan layanan kelompok, serta layanan informasi dan konsultasi. Layanan individu dan kelompok dilaksanakan untuk menangani hal-hal yang berkaitan dengan permasalahan perilaku menyimpang peserta didik, khususnya perilaku membolos, sedangkan layanan informasi dan konsultasi di khususkan bagi peserta didik yang dating untuk meminta informasi tentang studi lanjut. Selain itu, peserta didik juga terkadang datang keruang BK untuk meminta penjelasan atas sistem yang berlaku di SMA YP Unila Bandar Lampung.

Kesimpulan dari proses pelaksanaan kegiatan layanan bimbingan dan konseling di SMA YP Unila Bandar Lampung sudah berjalan dengan baik, hal ini terlihat dari tercapainya tujuan program yang telah direncanakan sebelumnya, yaitu penyelesaian masalah prilaku membolos peserta didik yang telah berkurang dari perilaku membolos peserta didik sebelumnya.

\section{Simpulan dan Saran}

Berdasarkan hasil pembahasan dan analisis pada bab sebelumnya, maka diperoleh kesimpulan sebagai berikut: 1) Tahap pelaksanaan layanan bimbingan dan konseling di SMA YP Unila Bandar Lampung terdiri dari tahap perencanaan, tahap pengorganisasian, tahap pelaksanaan dan kemudian tahap evaluasi. Tahapan- tahapan dilaksanakan sesuai dengan tujuan yang hendak di capai dalam kegiatan layanan bimbingan dan konseling tersebut. 2) 
Pelaksanaan kegiatan evaluasi program layanan bimbingan dan konseling dalam mengatasi perilaku membolos peserta didik kelas $\mathrm{X}$ di SMA YP Unila Bandar Lampung yaitu merumuskan masalah untuk mengetahui data-data yang di perlukan dalam perencanaan menyusun instrument untuk megetahui keberhasilan kegiatan layanan bimbingan dan konseling yang telah di laksanakan, mengumpulkan dan menganalisi, akhir dari program yang telah dijalankan, dan kemudian menindak lanjuti kegiatan yang telah dilaksanakan tersebut, evaluasi tersebut dengan melihat dan melakukan pencatata hasil kerja dan kinerja konselor, penilaian hasil kerja konselor, dan pengambilan tindakan perbaikan dan pengembangan.

\section{Daftar Pustaka}

Aqib, Z. (2012). Ikhtisar Bimbingan dan Konseling di Sekolah. Bandung: Yrama Widya.

Arifin, M. (2005). Pedoman Pelaksanaan Bimbingan dan Penyuluhan Agama, Edisi ke-2. Jakarta: Golden Terayon Press.

Devina, F. (2015, Mei 27). Wawancara Guru Bimbingan dan Konseling SMA YP Unila Bandar Lampung.

(2015, Mei 25). Dokumentasi SMA YP Unila Bandar Lampung.

Gunarsa, S. (2012). Konseling dan Psikoterapi. Jakarta: Penerbit Libri.

Gunarsa, S. D. (2004). Psikologi Praktis Anak, Remaja, dan Keluarga. Jakarta: Gunung Mulia.

Kartono, K. (2011). Patologi Sosial. Jakarta: Raja Grafindo Persada.

M.S, K. (2005). Metode Penelitian Kualitatif Bidang Filsafat. Yogyakarta: Paradigma.

Mardalis. (2004). Metode Penelitian Sebagai Pendekatan Proposal. Jakarta: Bumi Aksara.

Maryati, K., \& Suryawati, J. (2010). Sosiologi 1 B For Senior High School Grade X Semester 2. Jakarta: Gelora Aksara Pratama.

Mustaqim, \& Wahib, A. (2003). Psikologi Pendidikan. Jakarta: Rineka Cipta.

Nasional, D. P. (2003). Undang-Undang Sistem Pndidikan Nasional Nomor 20 tahun 2003. Jakarta: Sinar Grafika.

Nurikhsan, A. J. (2005). Landasan Bimbingan dan Konseling Islam. Bandung: PT. Remaja Rosdakarya.

Prayitno. (2001). Panduan Kegiatan Pengawasan dan Konseling di Sekolah. Jakarta: PT. Rineka Cipta.

Prayitno, \& Ermananti. (2004). Dasar-dasar Bimbingan dan Konseling. Jakarta: PT. Rineka Cipta.

Sarwono, S. W. (2011). Psikologi Remaja. Jakarta: Raja Grafindo Persada.

Suhertina. (2008). Pengantar Bimbingan dan Konseling di Sekolah. Pekanbaru: Suska Press.

Surya, M. (2005). Bina Keluarga, Cetakan Ke-2. Bandung: Aneka Ilmu.

Suryabrata, S. (2001). Metodologi Penelitian, Cetakan Ke-2. Jakarta: CV. Rajawali.

Thalib, S. B. (2010). Psikologi Pendidikan Berbasis Analisis Empiris Edukatif. Jakarta: Kencana.

Wahyuni Komalasari, d. (2011). Teori dan Teknik Konseling. Jakarta: Penerbit Indeks. 
Yunika, R., Alizamar, \& Sukmawati, I. (2013). Upaya Guru Bimbingan dan Konseling dalam mencegah perilaku bullying di SMA Negeri Se Kota Padang. Jurnal Ilmiah Konsling Vol. 2 No. 3. 
